\title{
NATURA I SENS TAJEMNICY WCIELENIA CHRYSTUSA ORAZ JEJ WPEYW \\ NA ŻYCIE MORALNO-DUCHOWE CZŁOWIEKA W ŚWIETLE KORESPONDENCJI ŚW. PAULINA Z NOLI
}

\section{OSOBA, PISMA I TEOLOGIA PAULINA Z NOLI}

Paulin urodził się ok. 355 roku w bogatej rodzinie senatorskiej. Jest możliwe, że był spokrewniony ze słynną ascetką Melanią Starszą. Miał brata, który w niewyjaśnionych okolicznościach poniósł gwałtowną śmierć. Rodzice Paulina umarli jako chrześcijanie, z czego jednak nie musi wynikać, że otrzymał od nich wychowanie chrześcijańskie ${ }^{1}$. Swoją edukację odbywał Paulin prawdopodobnie w szkole w Bordeaux, na czele której stał wówczas Auzoniusz, słynny galijski retor i poeta, wychowawca Gracjana na dworze cesarskim w Trewirze. Paulin ze swoim mistrzem związał się serdeczną przyjaźnią, która swój wyraz znajdowała także w wymienianej przez nich korespondencji. Być może przy pomocy protekcji związanego z dworem cesarskim Auzoniusza, rozpoczął Paulin godną uwagi karierę polityczną: w 378 r. mając 23 lata został consul suffectus $^{2}$, a w rok później prokonsulem Kampanii. Czas ten miał wielkie znaczenie dla jego rozwoju duchowego. Gdy na początku swojego urzędowania wziął udział w Noli w obchodach święta ku czci św. Feliksa, wywarły na nim głębokie wrażenie cuda dziejące się przy grobie tego świętego, których sam był świadkiem.

Działalność Paulina w latach następujących po zakończeniu działalności publicznej pozostaje tajemnicą. Możliwe, że pracował zawodowo jako adwokat. Być może w drodze powrotnej z Kampanii do Bordeaux, po zakończeniu sprawowania urzędu prokonsula, spotkał się w Mediolanie ze św. Ambrożym, albo się dłużej u niego zatrzymał, gdyż w sposób niedwuznaczny będzie podkreślał później wpływ, jaki wywarł na niego Biskup Mediolanu. Podczas swo-

${ }^{1}$ Na temat życia i działalności Paulina z Noli por. M. Skeb, Einleitung, w: Paulinus von Nola, Epistulae - Briefe, Fontes Christiani (FCh) 25,1, 5-38; zob. także SWP 318 oraz podręczniki patrologii.

${ }^{2}$ Consules suffecti - konsulowie wybierani lub później ustanawiani, gdy w danym roku zwolniło się miejsce urzędujących konsulów (np. z powodu śmierci), por. W. Litewski, Stownik encyklopedyczny prawa rzymskiego, Kraków 1998, s. 57. 
jego pobytu w Galii spotkał także w Vienne św. Marcina z Tours, który również wywarł na nim głębokie wrażenie. Następnie przeniósł się do Hiszpanii, gdzie ok. 385 roku poślubił majętną Theresię, rozpoczynając wspólne życie w dobrach w Hiszpanii i Galii; tu również przyszedł im na świat syn Celsus. Ok. 390 r. przyjął Paulin w Bordeaux z rąk biskupa Delfina chrzest, do którego w okresie katechumenatu przygotowywał go kapłan Amandus. Po gwałtownej i niespodziewanej śmierci brata, Paulin przeżywa niejako drugie nawrócenie, które skłania go do podjęcia jeszcze bardziej radykalnej formy życia chrześcijańskiego: sprzedaje swoją własność i rozpoczyna w Noli życie ascetyczne. Jednocześnie urzeczywistnia swój plan pozostania duchownym, zostając najpierw ostiariuszem. W Święto Bożego Narodzenia 394 r. biskup Barcelony Lampiusz udziela mu pod naciskiem wiernych święceń kapłańskich. W latach między 404 a 415 był biskupem Noli, gdzie umarł prawdopodobnie 22 czerwca $431 \mathrm{r}$. na zapalenie płuc.

Paulin prowadził obfitą korespondencję z najwybitniejszymi osobami swoich czasów. Wśród jego korespondentów figurują takie postacie jak: Marcin z Tours, Sulpicjusz Sewer, Hieronim, Ambroży, Augustyn i inni. Z korespondencji tej pozostało 51 listów, które mogą uchodzić za wzór stylu epistolograficznego. Ponadto po biskupie Noli zachowały się też Carmina 35 utworów napisanych różnym metrem na rozmaite, przeważnie religijne tematy.

Paulin w swoich listach i poematach nie prezentuje myśli teologicznej na sposób traktatów dogmatycznych. Punktami wyjścia w jego refleksji teologicznej nie są zainteresowania spekulatywne czy świadomy system teologiczny, lecz praktyka życia chrześcijańskiego. W kontekście zaś tej praktyki prezentuje pewną wybraną grupę tematów teologicznych (nauka trynitarna, łaska, Kościół, sakramenty, Maryja, święci, grzech, człowiek, sprawy ostateczne) ${ }^{3}$, jednak w sposobie, w jaki to czyni, nie dostrzegamy wnikliwego teologa; brak u niego własnej refleksji teologicznej, która pogłębiałaby dane Objawienia, zaczerpnięte $\mathrm{z}$ ksiąg Starego i Nowego Testamentu. W centrum jego teologicznych zainteresowań, które służyły mu przede wszystkim do przedstawienia ich praktycznych konsekwencji dla życia ascetycznego lub monastycznego, jest mimo wszystko chrystologia. Słowo Chrystus występuje w jego pismach aż 930 razy $^{4}$. Owa chrystologiczna myśl Paulina ukazana jest przede wszystkim w perspektywie historii zbawienia. W wielu jego listach można zauważyć następujący tematyczny schemat narracji: stworzenie - Stary Testament - wcielenie - krzyż i zmartwychwstanie Jezusa. Wszelkie zaś jego rozważania na te tematy, zmierzają głównie do uwypuklenia problemów związanych z ascetycznym i monastycznym sposobem życia.

\footnotetext{
${ }^{3}$ Por. Skeb, Einleitung, dz. cyt. s. 35.

4 Por. tamze.
} 


\section{TAJEMNICA WCIELENIA W LISTACH PAULINA Z NOLI}

W historiozbawczym schemacie teologicznym, jaki prezentuje Paulin z Noli, szczególne miejsce zajmuje tajemnica wcielenia Pańskiego. Chcąc ją scharakteryzować na podstawie jego listów, szukać będziemy odpowiedzi na pytania dotyczące natury wcielenia, jego głębokiego zbawczego sensu, a przede wszystkim skutków, jakie wcielenie wywiera na życie duchowe i ascetyczne chrześcijanina, na kształtowanie cnót życia chrześcijańskiego i na prowadzenie wewnętrznej walki duchowej, jaką w sobie podejmuje każdy asceta.

1. Natura wcielenia. Punktem wyjścia refleksji teologicznej Paulina na temat wcielenia są teksty nowotestamentalne, głównie prolog Ewangelii św. Jana, zwłaszcza werset: „A Słowo stało się ciałem i zamieszkało wśród nas. I oglądaliśmy Jego chwałę, chwałę, jaką Jednorodzony otrzymuje od Ojca, pełen łaski i prawdy" ( $\mathrm{J}$ 1,14) oraz nauczanie Pawła Apostoła zawarte w jego listach, szczególnie w Liście do Filipian: „On, istniejąc w postaci Bożej, nie skorzystał ze sposobności, aby na równi być z Bogiem, lecz ogołocił samego siebie, przyjąwszy postać sługi, stawszy się podobnym do ludzi. A w zewnętrznym przejawie, uznany za człowieka, uniżył samego siebie, stawszy się posłusznym aż do śmierci - i to śmierci krzyżowej" (Flp 2,6-8).

W świetle tych tekstów Paulin przyjmuje w Chrystusie po wcieleniu bóstwo i człowieczeństwo. We wcieleniu Chrystus połączył w sobie dwie przeciwstawne natury, boską i ludzką ${ }^{5}$. W swoich pismach Biskup Noli piętnował często herezje, które przeczą prawdziwości jednej bądź drugiej w Chrystusie. Wszystkie te herezje są, jego zdaniem, sprzeczne z nauką, jaką w prologu swojej Ewangelii przedstawił św. Jan, który spoczywał na piersi Pana i usiłował osiągnąć najwyższe zrozumienie Jego nauki. Stąd też nauka Jana o wcielonym Logosie zamyka usta wszystkim heretykom, którzy swoimi wypowiedziami w jakikolwiek sposób godzą w tajemnicę wcielenia ${ }^{6}$. Ich poglądom przeczy wprost prawda zawarta w prologu Ewangelii św. Jana, że Słowo, które było u Boga i było Bogiem, stało się ciałem .

Wcielony Chrystus jest więc w nauczaniu Biskupa z Noli zarówno Bogiem jak i człowiekiem. Paulin wyraźnie deklaruje tożsamość Syna Bożego i Syna Człowieczego, który jest Bogiem z Boga, a człowiekiem dla człowieka ${ }^{8}$. Przed swoim cielesnym przyjściem Chrystus jako Słowo istniał w Ojcu boskim istnieniem ${ }^{9}$. Jako Bóg i człowiek miał swoje boskie i ludzkie narodzenie. Pierwsze miało początek w boskim źródle. Syn Boży został przed czasami zrodzony

\footnotetext{
5 Por. Epistula 36,4, CSEL 29, 237, ed. Skeb FCh 25/3, 836.

${ }^{6}$ Por. Epistula 21,4, FCh 25,2, 462, CSEL 29, 152.

${ }^{7}$ Por, tamże.

${ }^{8}$ Por. Epistula 42,2, FCh 25/3, 934-936, CSEL 29, 360-361.

${ }^{9}$ Por. Epistula 23,14, FCh 25/2, 508, CSEL 29, 171.
} 
w niebie w niewysłowionym początku, a narodzenie to miało godność szczególną. Ale wielkiej godności nie było także pozbawione narodzenie cielesne, w którym Chrystus pochodzi z rodu królewskiego i kapłańskiego, na co wyraźnie wskazują jego rodowody przekazane przez ewangelistów - Mateusza i Łukasza ${ }^{10}$.

Pomimo człowieczeństwa Chrystusa, jakie wynika z jego ludzkich narodzin z Maryi Dziewicy, Biskup z Noli wyraźnie się dystansuje od słuszności nazywania Chrystusa naszym bratem, przede wszystkim z tego względu, że jego cielesne poczęcie i narodzenie nie miało nic wspólnego z ludzkim sposobem rozmnażania:

„Ten [Chrystus] nie był więc [naszym] bratem (jako Pan różnił się on od swoich niewolników w swoim statusie, a jako Bóg od ludzi w swojej naturze). Ale pomimo tego był on także człowiekiem. Napisano bowiem o nim: «On jest także człowiekiem i któż to zgłębi» (Jr 17,9). Także to nie czyni go jednak naszym bratem. Chociaż takie wyrażenie potwierdza miłość Boża, która w skromności wobec sług wypowiedziała słowa: «Będę głosić Twoje imię moim braciom» (Ps 22,23). Nie powinniśmy jednak rościć sobie prawa do nazywania Go [Chrystusa] bratem, dlatego, że w swojej laskawości stał się człowiekiem. Jego ludzkie narodzenie nie miało nic wspólnego z naszym narodzeniem, ze zwyczajnym sposobem naszego rozmnażania się. Stał się Ciałem poprzez Ducha Świętego, począł się i narodzil bez udziału tego, przez którego dziewictwo świętej matki uległoby naruszeniu. Dlatego On stał się w naszym ciele, ale bez tego, co przystaje do naszego ciała" ${ }^{11}$.

Mówiąc o człowieczeństwie Chrystusa Paulin wypowiada się przede wszystkim na temat ciała ludzkiego w Chrystusie: On zaistniał w takim samym, jak my, uniżonym ciele ${ }^{12}$. W nawiązaniu zaś do słów św. Pawła z Listu do Filipian Biskup Noli podkreśla, że Chrystus przyszedł na ziemię nie we wzniosłej postaci boskiej, ale przybrał postać sługi, której nie posiadał przed wcieleniem ${ }^{13}$. Przyjmując postać sługi swoją niewidzialną godność zasłonił widzialnym poniżeniem godności ${ }^{14}$. Ciało Jezusa nie było tylko podobnym do naszego ciała, lecz rzeczywistym ciałem ludzkim, z jednym wszakże wyjątkiem, bez skłonności do grzechu. Za św. Pawłem (Rz 8,3) Paulin podkreśla, że ciało Jezusa było tylko podobne do ciała grzesznego. On bowiem nie popełnił żadnego grzechu, lecz tylko ze względu na nas stał się grzechem ( 2 Kor 5,21): w postaci sługi odgrywał niejako rolę grzesznika ${ }^{15}$.

\footnotetext{
${ }^{10}$ Por. Epistula 29,7, FCh 25/2, 692-696, CSEL 29, 253.

11 Epistula 23,15, FCh 25/2, 508-510, CSEL 29, 171-172.

${ }_{12}$ Por. Epistula 12,3, FCh 25/1, 280, CSEL 29, 75.

13 Por. tamze.

14 Por. Epistula 12,4, FCh 25/1, 282, CSEL 29, 76-77.

15 Por. Epistula 12,6, FCh 25/1, 288, CSEL 29, 78-79.
} 
2. Sens wcielenia. W swoich listach Biskup Noli wielokrotnie powraca do wyjaśnień, dlaczego Syn Boży przyjął postać sługi? W jego wypowiedziach poczesne miejsce znajduje więc kwestia sensu tajemnicy wcielenia. Otóż przyczyną przybycia na ziemię w ludzkiej postaci Syna Bożego był, według Paulina, grzech pierworodny człowieka oraz jego skutki, które dotknęły cały rodzaj ludzki. Szczególnym skutkiem grzechu pierworodnego, o którym mówi, referując wspólną dla patrystyki myśl teologiczną, jest utrata wprawdzie nie obrazu Bożego, ale boskiego podobieństwa, jakie człowiek otrzymał od Boga w dziele stworzenia. Stało się to na skutek pychy człowieka, który zapragnął stać się równym Bogu. To podobieństwo Boże przywróciło człowiekowi dopiero wcielenie Boga w pokornej postaci sługi. Przez pokorę, a także przez pełne miłości posłuszeństwo, Chrystus pojednał na nowo z Ojcem świat, który został sprowadzony na złą drogę poprzez pychę i nieposłuszeństwo pierwszego rodzica, a także i przywrócił człowiekowi pierwotną godność ${ }^{16}$.

Dziełem tajemnicy zaistnienia Boga w ludzkim ciele dla przeciwdziałania skutkom grzechu pierworodnego było więc odnowienie pierwotnej natury ludzkiej. Chrystus zaistniał w takim samym jak ludzie uniżonym ciele, aby ukształtować je na wzór swojego chwalebnego ciała. Paulin posługuje się tutaj obrazem garncarza, który ma pełną władzę nad gliną. Jako taki Pan wszystkich, który zechciał zstąpić na nasz świat i przyjąć człowieczeństwo w swoim ciele, odnowił człowieka na ten sam sposób i moc, w jakiej go stworzył ${ }^{17}$. W jednym ze swych listów w taki oto sposób opisuje dramat grzechu pierworodnego i jego skutki:

„Już bowiem wszelkie ciało, to jest cały rodzaj ludzki, w ten sposób przesiąknął grzechem, że ani okład ani bandaż nie pomógł ułomnym i rannym; ponieważ występki nabierały na sile, a choroba mocniejsza od jakiegokolwiek środka leczniczego wykluczała każdy będący w mocy człowieka środek leczniczy, dlatego przybył Ten, który miał przyjść"18.

Zadaniem wcielonego Słowa było więc uleczenie ludzi z choroby grzechu. Nieco dalej w tym samym Liście Biskup Noli wskazuje na symbolikę dwu pojęć - drzewa i dziewicy, obrazującą w następujący sposób tę prawdę:

„Celem dostrzeżenia wielkości tego planu i daru, posiadamy światło od Tego, który nas oświeca ze wzgórz wiekuistych. Gdy wzniesiemy w ich stronę nasze oczy, możemy zobaczyć, że ponownie znaleźliśmy się na tych samych drogach, gdzie znajdują się drzewo i dziewica, z powodu których zginęliśmy. Powróciliśmy na te drogi, ale nie po to, aby ponownie zginąć na skutek pychy, ale przeciwnie, aby z pokorą nawrócić się" 19 .

\footnotetext{
${ }^{16}$ Por. Epistula 24,9, FCh 25/2, 592-594,CSEL 25, 209.

${ }^{17}$ Por. Epistula 12,3, FCh 25,1, 280, CSEL 29, 75.

18 Epistula 12,3, dz. FCh 25/1, 280, CSEL 29, 75.

19 Epistula 12,4, FCh 25/1, 282, CSEL 29, 76.
} 
U początków dziejów ludzkości stanęło rajskie drzewo rozróżniania dobra i zła oraz dziewica Ewa. Ludzka pycha doprowadziła wówczas do grzesznego upadku. Ponownie jednak na drodze ludzkości stanęła dziewica Maryja i drzewo krzyża. W tym wypadku przeciwieństwo pychy, czyli pokora jest wyrazem odwrócenia się od grzechu. W tym tekście zauważamy związki wcielenia z tajemnicą odkupienia, a także Paulina jako moralistę i nauczyciela ascezy, który w związku z treściami dotyczącymi istotnych prawd historiozbawczych mówi o duchowej walce człowieka z wadami i cnotach, czego przykładem jest Chrystus. Chrześcijanin powinien naśladować pokorę Chrystusa widoczną w tajemnicach wcielenia i odkupienia.

W innym $z$ listów Biskup Noli ukazuje sens i skutki tajemnicy wcielenia w kontekście ewangelicznej przypowieści Jezusa o miłosiernym Samarytaninie (Łk 10,33-37). Wcielenie Słowa przyrównuje Paulin do jucznego zwierzęcia, na które Chrystus jako prawdziwy Samarytanin wziął leżącego na swej drodze życia, rannego i obrabowanego przez diabła człowieka, którego potem leczył oliwą łaski i winem męki ${ }^{20}$. Po raz kolejny w myśli Paulina zauważamy wypowiedź, w której łączy on ściśle wcielenie z odkupieniem. To drugie wyraźnie zakłada pierwsze. Do takiego wniosku dochodzimy, choćby na podstawie następujących słów Biskupa:

„Bóg nie udzielił swojego daru pojednania, ponieważ On sam był pojednaniem, i nie dał żadnego okupu dla wykupienia swojej duszy, lecz naszej, ponieważ jako Odkupiciel nie potrzebował odkupienia. To my zaprzedani grzechowi potrzebowaliśmy okupu dla wykupienia, i dlatego On stał się człowiekiem z naszego powodu, z naszego powodu przybrał postać sługi, z naszego powodu stał się synem służebnicy. On błogosławiony i sprawca świętości świętych stał się mimo to dla nas grzechem i przekleństwem (2 Kor 5,21; Ga 3,13), czym nie był wcześniej, aby nas, którzy na podstawie przekroczenia prawa byliśmy grzechem, i na podstawie skazania - przekleństwem, uwolnić od jednego i drugiego w ten sposób, że jedno i drugie w swoim ciele przybił do krzyża (Kol 2,14). Sądzę, że w tym tkwi racja słów: brat nie wykupuje, człowiek odkupi, ponieważ tych, których brat nie odkupił, to znaczy prorok i prawodawca, który był tylko człowiekiem, odkupił ten człowiek, który był Bogiem. Bóg bowiem rzecze: «Bóg mianowicie w Chrystusie pojednał świat ze sobą" (2 Kor 5,19$)$ "21.

Nieco dalej w tym samym liście Paulina znajdujemy dłuższą wypowiedź, w której przedstawia on poprzedzone wcieleniem odkupienie, jako sprawiedliwe zwycięstwo Syna Bożego nad demonem. Wypowiedzią tą Paulin wpisuje się w bogatą tradycję zarówno greckich, jak i łacińskich Ojców Kościoła. Ideę tak ujętego odkupienia Biskup Noli zaczerpnął od takich poprzedników jak: Ireneusz z Lyonu, Orygenes, Bazyli Wielki, Grzegorz z Nyssy, Hilary z Poitiers

20 Por. Epistula 23,14, FCh 25/2,508, CSEL 29, 171.

21 Epistula 23,15, FCh 25/2, 508-510, CSEL 29, 172. 
czy Ambrozjaster. Tę samą myśl znajdujemy także w dziełach Augustyna, a później Leona Wielkiego i Cezarego z Arles. W ujęciu Paulina z Noli przedstawia się ona następująco: skreślenia dłużnego zapisu śmierci (por. Kol 2,14) i pokonania fałszywego oskarżyciela (por. Ps 72,4) mógł dokonać jedynie człowiek w rodzaju Chrystusa. Do walki z szatanem przystąpił on w ludzkiej postaci, bo tylko dzięki temu mógł dokonać zwycięstwa i zadośćuczynić prawu sprawiedliwości. Na skutek grzesznego upadku pierwszego człowieka oskarżyciel domagał się jako grzesznego całego potomstwa pierwszych ludzi. Za tym roszczeniem - według Paulina - stała przede wszystkim złośliwa żądza. Roszczenie to jednak było poniekąd sprawiedliwe oraz zgodne z prawem i przyczyniło się do jego zwycięstwa. Sytuacja wyglądała w ten sposób do momentu, kiedy targnął się na życie sprawiedliwego, który nie tylko był bez grzechu, ale urodził się bez jakiejkolwiek żądzy, którą oskarżyciel ujarzmił wszystkich tych, których uwięził. Wskutek owego wielkiego aktu niesprawiedliwości dokonanego na Chrystusie został on zmuszony do zwolnienia tych, którzy uwierzą w tego, którego on w sposób całkowicie bezprawny zniszczył. W ten sposób Odkupiciel uregulował rachunek, którego nie był winny ${ }^{22}$. Do tej myśli nawiązuje Paulin w innym jeszcze liście, gdzie pisze:

\begin{abstract}
„On, który sam był wolny od grzechu, potępił źródło naszego grzechu, niszcząc poprzez krew swojej męki, skierowany przeciwko nam cyrograf śmiertelnego edyktu (por. Kol 2,14) oraz nieprzyjaźń, która oddzielała nas od Boga wskutek grzechów (Ef 2,16), i triumfował nad wrogimi mocami w swoim ciele, dając nam przykład życia i pokonywania w nas samych duchowych i niewidzialnych wrogów w duchowej i niewidzialnej walce. Ta walka toczy się pomiędzy prawem ducha a prawem ciała, starając się nas przymusić do prawa grzechu $(\operatorname{Rz} 7,23)^{, 23}$.
\end{abstract}

\title{
III. SENS I SKUTKI TAJEMNICY WCIELENIA A ŻYCIE MORALNO-ASCETYCZNE CZŁOWIEKA
}

Powyższy tekst oprócz przypomnienia raz jeszcze zbawczej funkcji wcielenia i odkupienia, podkreśla ponadto dwie sprawy, które wskazują na pewne praktyczne wnioski i zastosowania, jakie z tajemnicy wcielenia wynikają dla życia moralno-ascetycznego człowieka. Wcielony Syn Boży poprzez swoją mękę, $\mathrm{z}$ jednej strony $\mathrm{w}$ duchowej walce pokonał niewidzialnych wrogów, a z drugiej dał człowiekowi przykład, w jaki sposób ma toczyć duchową walkę i jak w niej zwyciężać; ze strony człowieka jest jednak potrzebna wola naśladowania Chrystusa.

22 Por. Epistula 23,15, FCh 25/2, 510-512, CSEL 29, 172-173.

23 Epistula 37,2, FCh 25/3, 842-844, CSEL 29, 318-319. 
1. Walka duchowa. Jako skutek grzechu pierworodnego istnieje w człowieku wewnętrzne przeciwieństwo i walka ${ }^{24}$. Mówiąc o naturze człowieka Biskup Noli wskazuje na liczne istniejące w niej przeciwieństwa. Śledząc całą jego myśl antropologiczną można wskazać na następujące przeciwieństwa, które w naturze człowieka pozostają między sobą w stanie walki:

Człowiek zewnętrzny (homo exterior) - człowiek wewnętrzny (homo interior) Ciało (caro, corpus), członki (membra) - dusza (anima, animus).

Ciało (caro, corpus) - duch (mens, spiritus)

Duch (spiritus, mens) - dusza (anima) - ciało (caro), przy czym anima nie łączy się ani ze spiritus / mens ani z caro, która każdorazowo może stanowić niższą lub wyższą część ludzkiej natury ${ }^{25}$.

Widoczna w antropologii Paulina koncepcja duchowej walki obraca się przede wszystkim wokół myśli biblijnej z listów św. Pawła Apostoła. Chodzi tu przede wszystkim o dwa teksty. Pierwszy z nich pochodzi z Listu do Rzymian:

„Wiemy przecież, że Prawo jest duchowe. A ja jestem cielesny, zaprzedany w niewolę grzechu. Nie rozumiem bowiem tego, co czynię, bo nie czynię tego, co chcę, ale to, czego nienawidzę - to właśnie czynię. Jeżeli zaś czynię to, czego nie chcę, to tym samym przyznaję Prawu, że jest dobre. A zatem już nie ja to czynię, ale mieszkający we mnie grzech. Jestem bowiem świadom, że we mnie, to jest w moim ciele, nie mieszka dobro; bo łatwo przychodzi mi chcieć tego, co dobre, ale wykonać - nie. Nie czynię bowiem dobra, którego chcę, ale czynię to zło, którego nie chcę. Jeżeli zaś czynię to, czego nie chcę, już nie ja to czynię, ale grzech, który we mnie mieszka. A zatem stwierdzam w sobie to prawo, że gdy chcę czynić dobro, narzuca mi się zło. Albowiem wewnętrzny człowiek [we mnie] ma upodobanie zgodne z Prawem Bożym. W członkach zaś moich spostrzegam prawo inne, które toczy walkę z prawem mojego umysłu i podbija mnie w niewolę pod prawo grzechu mieszkającego w moich członkach. Nieszczęsny ja człowiek! Któż mnie wyzwoli z ciała, [co wiedzie ku] tej śmierci? Dzięki niech będą Bogu przez Jezusa Chrystusa, Pana naszego! Tak więc umysłem służę Prawu Bożemu, ciałem zaś - prawu grzechu" ( $\mathrm{Rz} 7,14-25)$.

\section{Drugim tekstem jest fragment Listu do Galatów:}

„Ciało bowiem do czego innego dąży niż duch, a duch do czego innego niż ciało, i stąd nie ma między nimi zgody, tak że nie czynicie tego, co chcecie" (Ga 5,17).

Tę będącą skutkiem grzechu pierworodnego wewnętrzną walkę, jaka toczy się w człowieku, rozstrzygnął Chrystus, a znaczny w tym udział ma fakt, czy, ściślej mówiąc, natura Jego wcielenia. Paulin przyporządkowuje ciało ludzkiej naturze Chrystusa, a stronę duchową - boskiej. Te dwie przeciwstawne natury połączył w sobie Chrystus w tajemnicy wcielenia. On jako Pośrednik pomiędzy

${ }^{24}$ Por. Epistula 24,10, FCh 25/2, 596-598; 24,13, FCh 25/2, 602-604; 30,2, FCh 25/2, 716-718.

25 Por. M. Skeb, Einleitung, dz. cyt., s. 55-56. 
Bogiem a ludźmi doprowadził w ten sposób także do jedności ciała z duszą. Ten fakt zwycięstwa Chrystusa w owej wewnętrznej walce naświetla Paulin w swojej korespondencji w kontekście innego fragmentu z Listu św. Pawła do Efezjan:

\begin{abstract}
„On bowiem jest naszym pokojem. On, który obie części [ludzkości] uczynił jednością, bo zburzył rozdzielający je mur - wrogość. W swym ciele pozbawił On mocy Prawo przykazań, wyrażone w zarządzeniach, aby z dwóch [rodzajów ludzi] stworzyć w sobie jednego nowego człowieka, wprowadzając pokój, i [w ten sposób] jednych, jak i drugich znów pojednać z Bogiem w jednym Ciele przez krzyż, w sobie zadawszy śmierć wrogości” (Ef 2,14-16).
\end{abstract}

Przyjrzyjmy się teraz teologicznym i duchowym wnioskom, jakie Biskup Noli wyciąga z tego tekstu Apostoła Narodów w kontekście tajemnicy wcielenia i odkupienia. W jednym ze swoich listów po przytoczeniu powyższych tekstów św. Pawła dodaje:

„Stało się to nie tylko dlatego, aby wiara Żydów i pogan zjednoczyła się w Chrystusie, lecz aby w każdym z nas, którzy wierzymy, w naszej naturze się zjednoczyła, a niezgoda, która przedtem w nas panowała, kiedy stworzenie cielesne było w konflikcie z wolą ducha, zakończyła się pokojem, jaki daje wiara. Teraz zaś owa stara walka, w której prawo grzechu przeciwstawiało się prawu Boga, zostaje wyciszona w Chrystusie, ponieważ duch służący Bogu temperuje wiarą poddaną sobie duszę i odwrotnie - towarzyszące ciało zachęca służącą Bogu duszę do pełnego posłuszeństwa ${ }^{26}$.

Jak wynika z powyższego, Chrystus, po pierwsze, zburzył rozdzielający mur wrogości pomiędzy Żydami a poganami, którzy zjednoczyli się w jednej wierze w Chrystusa, a po drugie otworzył drogę do położenia kresu rozdwojenia, jakie dokonuje się we wnętrzu każdego człowieka pomiędzy tym co cielesne, a tym co duchowe. Ten mur podziału burzy pokój, jaki daje wiara w Chrystusa, który jako pierwszy w swej naturze zburzył mur pomiędzy tym co boskie, a tym co ludzkie.

Powyższą wypowiedź Paulin poprzedza refleksją w odniesieniu do słów z Księgi Liczb, które w sensie historycznym wypowiedzieli ongiś posłańcy izraelscy do Sichona, króla Amorytów: „Nie zboczymy ani na lewo ani na prawo, lecz pójdziemy drogą królewską" (Lb 21,22). Aplikując ten tekst do duchowej rzeczywistości i wiary w Chrystusa, Biskup Noli podkreśla, że królewską drogą jest dla człowieka Chrystus, Pośrednik między Bogiem a ludźmi, który porządkuje w nas to co boskie, i to co ludzkie. Porządek, jaki wprowadza Chrystus w rozdwojonej naturze człowieka, daje możliwość zwycięstwa w walce duchowej, to jest uniknięcia zbytniego skręcenia w lewo bądź prawo. Strona lewa w refleksji Biskupa Noli oznacza grzechy, które prowadzą do śmierci, strona zaś prawa - pełną pychy zuchwałość. Pozostanie na drodze królewskiej

${ }^{26}$ Epistula 12,6, FCh 25/1, 288, CSEL 29,79.

VOX PATRUM 20 (2000), 1. 38-39- 19 
oznacza trzymanie się zbawiennego umiaru ${ }^{27}$, drogi środka, czyli życia cnotliwego. Skrajności, jako wady, prowadzą zawsze do zguby.

2. Naśladowanie Chrystusa. Chrystus zwyciężając w duchowej walce i przywracając pokój pomiędzy tym, co cielesne, a tym co duchowe, dał przede wszystkim wzór i przykład drogi, po której powinien kroczyć każdy wierzący w Niego. To naśladowanie Chrystusa jest odpowiedzią na Jego wcielenie i odkupienie. $\mathrm{W}$ jednym $\mathrm{z}$ listów Paulin pisze:

„To jest jego walka, którą my walczymy, i jego korona, którą zwyciężając osiągamy, ponieważ jesteśmy członkami jego ciała; jednak tylko wtedy gdy umartwimy na ziemi nasze członki, staną się one bronią sprawiedliwości” 28 .

Chrystus jako pierwszy prowadził walkę, którą teraz toczą wierzący w Niego, należący do Kościoła chrześcijanie, by zdobyć na skutek zwycięstwa Jego koronę. W tej walce, jak i w zwycięstwie Paulin dostrzega przede wszystkim szczególną rolę ascezy i umartwiania ciała. To one prowadzą człowieka do chwały na kształt chwały Bożej pod warunkiem, że człowiek idzie za przykładem Chrystusa:

„Dobry Pan działał i codziennie działa na rzecz tego, abyśmy osiągnęli chwałę na kształt chwały Bożej, kiedy będziemy podążać za przykładem, jaki daje nam Chrystus. Wierzy bowiem, że na skutek kierownictwa Najwyższego dokonujemy postępu w łagodzeniu naszej natury, aby nad nami znajdowała się Jego łaska, gdy będziemy wiedli życie pamiętając o Nim" ${ }^{29}$.

Przeprowadzona analiza wybranych listów św. Paulina z Noli pod kątem jego nauki na temat wcielenia Syna Bożego pozwala stwierdzić, że Autor w nauczaniu na ten temat koncentruje swoją uwagę przede wszystkim na sensie tajemnicy wcielenia oraz jej znaczeniu dla odkupienia człowieka. Mniej bogata w sensie głębszej refleksji teologicznej jest jego prezentacja samej istoty (natury) wcielenia. Sposób, w jaki Biskup Noli traktuje ten temat nie charakteryzuje go jako oryginalnego i wnikliwego teologa. W swojej refleksji na temat natury wcielenia nie wychodzi zbyt daleko poza świadectwa biblijne, które cytuje bardzo obficie. Znacznie więcej ma Autor do powiedzenia odnośnie do roli i miejsca wcielenia w dziejach zbawienia, co wpiśuje się bardzo dobrze

\footnotetext{
${ }^{27}$ Por. Epistula 12,4, FCh 25/2, 282-284, CSEL 29, 76-77.

28 Epistula 40,10, FCh 25/3, 916, CSEL 29, 352.

${ }^{29}$ Epistula 12,4, FCh 25/1, 284, CSEL 29, 76.
} 
we wskazany centralny temat jego teologicznej refleksji, jakim jest historia zbawienia wraz z centralnym w niej miejscem dla Chrystusa i Jego dzieła. Poruszając się w tym historiozbawczym schemacie Paulin pogłębia dane Objawienia na ten temat, przede wszystkim Listy św. Pawła Apostoła. Będąc w pewnych punktach kontynuatorem wcześniejszej patrystycznej tradycji, w innych kwestiach okazuje się bardziej oryginalnym myślicielem, przede wszystkim w aplikowaniu nauki o wcieleniu Syna Bożego do życia duchowego człowieka.

NATURE AND MEANING OF INCARNATIONS MYSTERY

OF CHRIST AND HER INFLUENCE ON MORAL AND SPIRITUAL LIFE OF MAN IN CORRESPONDENCE OF ST. PAULINE OF NOLA

(Summary)

The article presents learning of saint Pauline, bishop of Nola on theme incarnation of God's Son. One talk overed in turn nature and meaning of incarnation and her influence and results on moral and spiritual life of man, first of all influence on victory of man in spiritual fight, which runs in man among spirit and body. 